\title{
DESIGN OF TSUNAMI DETECTOR BASED SMS USING ARDUINO AND SIM900A TO GSM/GPRS MODULE
}

\author{
Puput Dani Prasetyo Adi, Rahman Arifuddin
}

\begin{abstract}
Tsunamis are one of the most unforeseen natural disasters, factors or signs of a tsunami occurring among others is the sudden reflux of seawater which is due to the broken plate of the underlying sea floor receding water, the plate fault is caused by seismic ground-based earthquakes, areas ever experienced a previous fault is likely to occur in the same quake place this is because the slabs can not coalesce or return like the original. for it needed a prototype system that can detecting the early detection of a tsunami that could cost many lives.

The prototype system created is equipped with a fibration sensor to detect vibration and Ultrasonic sensors to detect distances, after of some varible detected then the data will be transmitted remotely via SIM900A as GSM / GPRS Module
\end{abstract}

Keywords : Fibration, Ultrasonic, SIM900A, Tsunami

\section{INTRODUCTION}

$\mathrm{T}$ he beginning of the idea of making this research is how the tsunami disaster can be avoided and overcome as quickly as possible with fast and accurate information. sending data remotely is the right answer, how to transmit data quickly remotely across GSM or GPRS Module device or use SMS Broadcast. design prototype made used waterproof coatings that cause rust. prototype placed on the shore that has been studied to what extent a standard or normal water debit. the layout of the prototype will be depicted on figure 5. as for hardware used in building prototype is Arduino UNO or DF-RDuino Board, SIM900A, Ultrasonic sensor HCSR04 (4 Feet), 16x2 LCD, Buzzer 5 Volt, Potentiometer, Male-Female Wire, Male-Female Wire, Breadboard, USB Cable and Android Smartphone and the software used is Arduino 1.0.5 Free for IDE Arduino and build the C Language program, Fritzing for the Schematic and PCB Desain layout and Notepad ++ for editing $\mathrm{C}$ Language program for IDE Arduino.

Puput Dani Prasetyo Adi is with the Electrical Engineering Departement of Universitas Merdeka Malang, Malang, Indonesia (corresponding author provide phone +6282143634134; email puput.danny@unmer.ac.id)

Rahman Arifuddin is with the Electrical Engineering Departement of Universitas Merdeka Malang, Malang, Indonesia (corresponding author provide phone :+62 $341582881,,+62341588395$; email rahman.arifuddin@unmer.ac.id )
Sensor placement is at an estimated distance of $300 \mathrm{~cm}$ or 3 meters from sea level, on the prototype indicator there are 3 states that are safe, danger and out of reach. when safe conditions mean sea water conditions are still in safe range according to coding program, in this condition there is no data sent to GSM SIM900A Module because it is in the possibility of safe distance. In condition -2 that is dangerous condition. This condition allows the transmission of sensor data to GSM Module SIM900A due to the position or condition of the drastic drastic sea water that triggers the possibility of a tsunami, after ultrasonic sensors read the sea water distance conditions in accordance with the coding program that has been entered, then the data sent to SIM900A for later sent to Smartphone. In the 3rd condition the sensor does not read any normal distance or it is said out of the range. In this condition the sensor does not provide any output at all, and awaits the occurrence of distance changes in the sea water in accordance with the program code processed by the Arduino under normal or legible conditions.

\section{RELATED WORK}

[1] Dr. rer. nat. Widi Setiawan, Dr. Purwadi Rahardjo MSc, Alim Safari, S.T. ( Inkubator-Technology )

The method of measuring the distance with the ultrasonic sensor is to utilize ultrasonic wave velocity constant of $1130 \mathrm{feet} / \mathrm{second}$ or $344 \mathrm{~m} / \mathrm{s}$ so to cover a distance of $1 \mathrm{~cm}$ takes $29 \mu \mathrm{s}$. by calculating the ultrasonic travel time then divided by $29 \mu \mathrm{s}$ it will get the distance.

For PING sensor then the measurement step as follows: Create an ultrasonic signal with a frequency of $40 \mathrm{KHz}$ by means of a SIG pin made HIGH for $2 \mu \mathrm{s} \mathrm{s} / \mathrm{d} 5 \mu \mathrm{s}$. Wait until about $750 \mu \mathrm{s}$. The ultrasonic wave will radiate up towards the target then it will be reflected back to the PING sensor. As long as the ultrasonic has not been received back by the sensor, the logic condition of the SIG pin is HIGH. Turn on the timer (to calculate the travel time) and wait until the ultrasonic wave is received back (after reflected) with the SIG pin marks changed to LOW. If the ultrasonic signal has been received again turn the timer off. Calculated travel time is 2 times the distance that is send - receive (or common language go home). The travel time of the sensor with the target means the total travel time divided by 2 . 
Distance between sensor and target $=$ sensor travel time to target / $29 \mu \mathrm{s}(\mathrm{cm})$.

[2] Rafi Pradata, Mochammad Rif'an and Eka Maulana, Brawijaya University.

SIM900A device is used as one of the devices to secure the car, in addition to the security system that already owned the car ie alarm, magnet and other keys. SIM900A device installed in prototype allows to know the location of the car and can switch off and start the engine automatically using the module device you created.

\section{SISTEM DEVELOPMENT}

\section{A. Prototype}

The resulting prototype can be seen in the figure 1 . prototype was first made using breadboard which then developed using PCB. The prototype design stages are as follows : The basic wiring is the Arduino Board and SIM900A, shown in figure 1 . On the 2 nd wiring we will connect the Arduino with LCD device, Ultrasonic Sensor, Buzzer and Potentiometer, shown in figure 2.

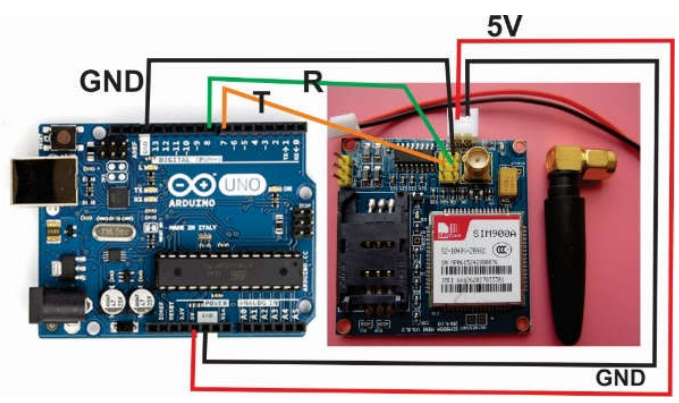

Fig.1 Wiring Arduino Board and SIM900A

In Figure 1 shows the first step in connecting using SIM900A, there are 5 pins that will connect to the Arduino Board, the first T (Transmitter) to Digital Pin 7 Arduino, R (Receiver) to Digital Pin 8 Arduino, GND (Ground) to GND Arduino, and $5 \mathrm{v}$ power supply to pin 5 Volt Arduino. In SIM900A Module there is SIM Port, SIM This port is used to place SIM card, Provider SIM card that can be used is TELKOMSEL, XL OR INDOSAT, Or other card according to area or location you are.

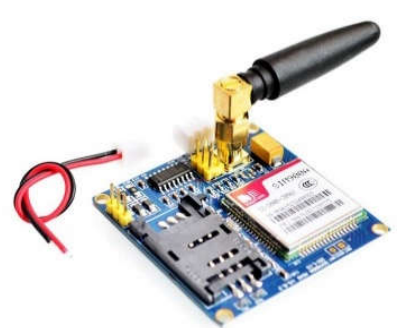

Fig. 2. Modul SIM900A

Next is the setting of SIM900A can be seen in SIM900A configuration -1 . There are 2 settings in SIM900A Module which is setting when send Sort Message Service (SMS) on AT-Command and Settings when receiving Sort Message Service (SMS) on AT-Command. When sending using AT + CMGS commands and when receiving or viewing incoming messages using AT + CMGL commands.

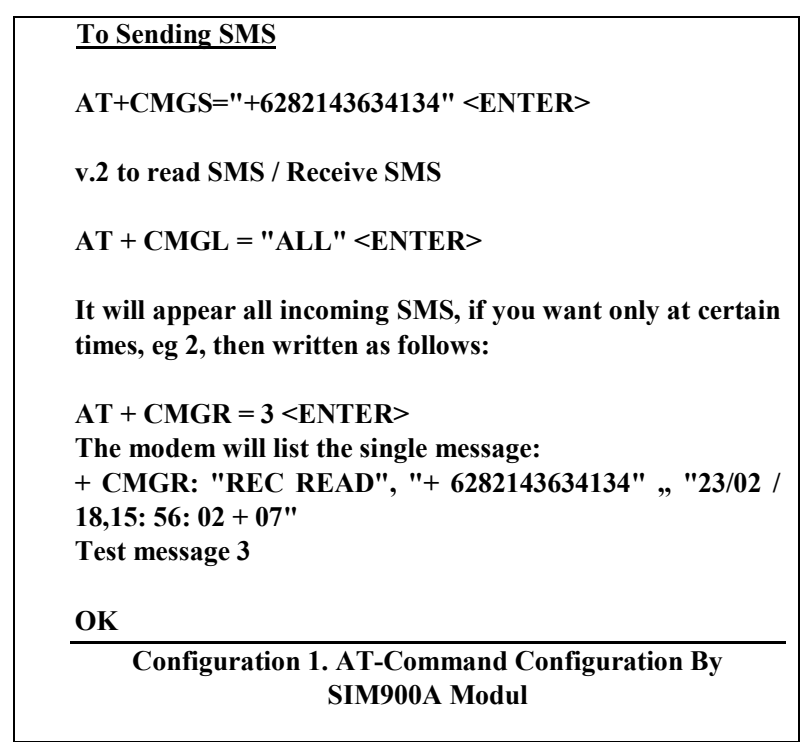

After configuration on Arduino and SIM900A Microcontroller has been successful, immediately stored its program code such as AT-Command on SIM900A on IDE Arduino. Then the next stage is the installation of $16 \times 2 \mathrm{LCD}$ as an indicator and ultrasonic sensor as a data giver distance. 16x2 LCD with potentiometer to adjust brightness and Contrast from $16 \times 2$ LCD. Settings and Wiring can be seen in Figure 2 .

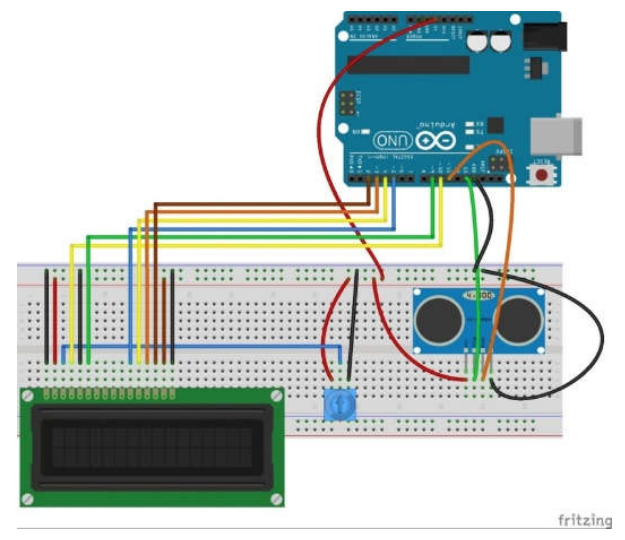

Fig. 3 Arduino Board Wiring, 16x2 LCD and Ultrasonic Sensor

After the installation and program code in Figure 3 is completed, added again Buzzer as voice indicator. Buzzer is used as an indicator when distance indicates unsafe state, for that besides $16 \times 2$ LCD as indicator, Buzzer is expected to increase the Indicator's complexity on prototype. Installation of buzzer shown in figure 4, Buzzer used has a voltage of 5 volts, buzzer or piezo has 2 pins that is GND and Data, for Data entry on Digital pin 8 Arduino Board. for wiring in figure 4 there is no change like figure 3 , the difference is the addition of voice indicator piezo or buzzer 5 Volt. The function of the buzzer is as a complement to the prototype, although the buzzer function here is not too important because there is already a SIM900A role as a data sender or a very important indicator. 


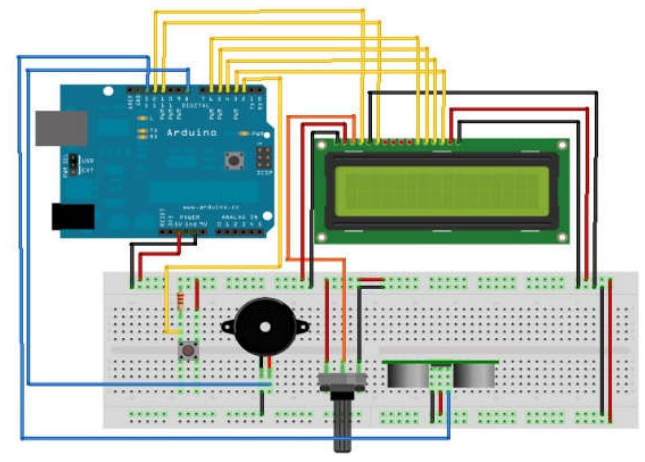

Fig.4 Arduino Board, 16x2 LCD, Ultrasonic Sensor and Buzzer Wiring

After the addition of buzzer to the prototype successfully completed, the next step is to combine the schematic in the picture 1, 3 and 4 so that can be seen schematic in Figure 5. Figure 5 describes the merger between GSM Module SIM900A device with ultrasonic sensor that has been combined in one module.

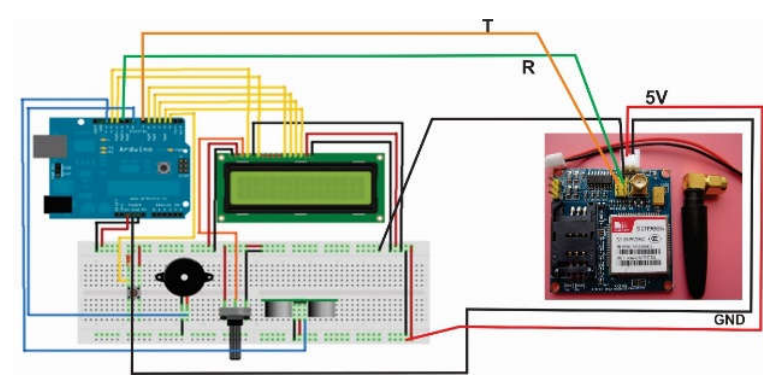

Fig. 5 Wiring with all SIM900A devices and GSM Shield

In figure $05, \mathrm{R}$ should be at pin 8 and $\mathrm{T}$ at pin 7 , because pin 8 is used buzzer so in connect to pin 9 for $\mathrm{R}$ its. It is the same, has no effect. Stay changed on Source code alone. Similarly, the original source code uses Arduino 1.0.5 of the no. 4 circuit above, for the buzzer to be at pin 12. TX, RX is on pins 7 and 8 .

The next step is to do testing and coding then do the test directly, Figure 6 shows the prototype testing.

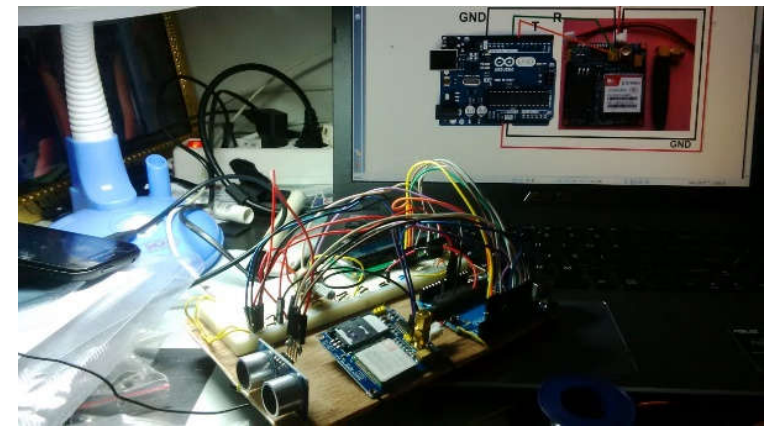

Fig.6 Prototype Tsunami Detector

\section{B. Program Code}

The program code used is Arduino C language that is processed on Arduino's Integrated Development of Environtment. The excerpt of the program is shown in Pseudocode -1 .

\#define trigPin, echo, Buzzer, LiquidCrystal LCD,

SoftwareSerial GPRS

If GPRS detect

Serial.write, GPRS.read long duration, distance;

duration $=$ pulseIn $($ echoPin, HIGH);

distance $=($ duration $/ 2) / 29.1$;

if $($ distance $>=1 \& \&$ distance $<=20$ )

\{

digitalWrite(Buzzer,LOW);

LCD.print(" Aman ");

LCD.println(" cm ");

\}

if (distance $>=30 \& \&$ distance $<=199$ )

\{

Serial.print("Warning !!! Air Laut Surut Berpotensi Terjadinya

Tsunami ");

GPRS.println("AT+CMGF=1");

delay(500);

GPRS.println("AT+CMGS=।"+6281227103387\"');

delay(500);

GPRS.print("WARNING Air Laut Surut Berpotensi Terjadinya

Tsunami ");

GPRS.write(0x1a);

delay (500);

digitalWrite(Buzzer,HIGH);

LCD.print(" Bahaya!!! ");

LCD.println(" cm ");

\}

if $($ distance $>=320 \|$ distance $<=0)$

\{

Serial.println("Diluar Jangkauan");

LCD.print("Diluar Jangkauan");

\}

Pseudo-code 1. Algoritma for classification of Sea Water condition

\section{PERFORMANCE EVALUATION AND RESULT}

The first stage of testing is prototype to detect high low sea water causing prototype will take the initial conclusion that the possibility of tsunami occurrence. In this test confirmed the distance is read by the ultrasonic sensor, for example in the range of 1 meter, ultrasonic sensors can still read any distance changes. The next stage is from the data provided by ultrasonic sensors will then be sent to the Smartphone via GSM Modem SIM900A module. Here is the ultrasonic sensor testing of distance, the maximum distance of the ultrasonic data pulse is $319 \mathrm{~cm}$ or $3,19 \mathrm{~m}$. above that ultrasonic range can not read, the data read by ultrasonic is the high low of sea water. 
Tabel 1. The condition of the seawater on sending data to the GSM module SIM900A

\begin{tabular}{|c|l|c|c|}
\hline No & $\begin{array}{c}\text { Tinggi sensor } \\
\text { dengan air } \\
\text { laut }(\mathbf{C m})\end{array}$ & $\begin{array}{c}\text { Pengiriman } \\
\text { data ke GSM } \\
\text { Modul } \\
\text { SIM900A }\end{array}$ & $\begin{array}{c}\text { Buzzer } \\
\text { Condition } \\
\text { on } \\
\text { Prototype }\end{array}$ \\
\hline 1 & $\begin{array}{l}\text { Distance }>=1 \& \\
<=199\end{array}$ & No & off \\
\hline 2 & $\begin{array}{c}\text { Distance }>=200 \\
\&<=300\end{array}$ & $\begin{array}{c}\text { Sending } \\
\text { Message } \\
\text { Warning }\end{array}$ & On \\
\hline 3 & $\begin{array}{l}\text { Distance }>= \\
319 \|<=0\end{array}$ & Out of ranges & Off \\
\hline
\end{tabular}

The reading of ultranosic sensors to the distance to the sea water is expressed in percent (\%) shown in the graph in figure 6.

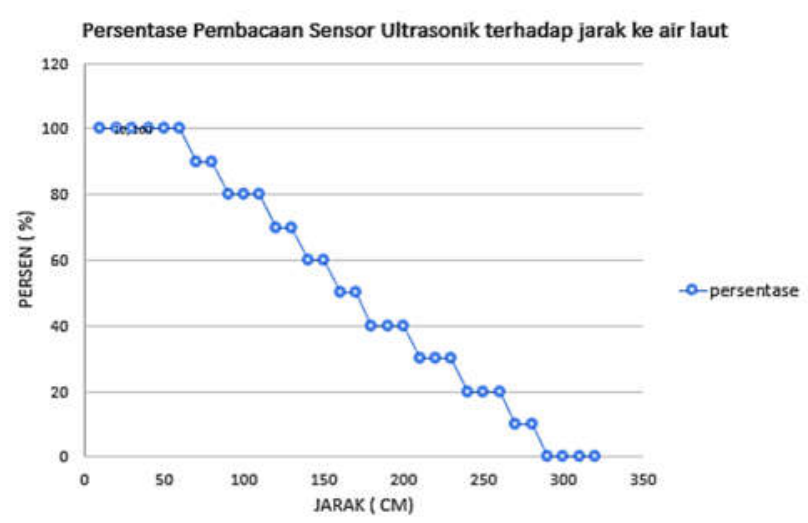

Fig. 6 Graph of percentage (\%) ultrasonic sensor readings against distance to sea water.

The prototype design that will be installed on the shoreline is depicted in Fig. 7, there are 4 possible conditions during the tsunami. The first condition is a safe or normal situation, in which case the position of the seawater and the sensor is the safe position shown in Table 1. The second condition is the breaking of the plates which makes the waves, after this slab is broken sea water conditions are shown in the next picture is receding or drastic receding conditions so that the sensor directly read the sea water range conditions and sensors that are not normal so that the sensor send SMS and alarm alert sounds. next condition is a tsunami condition where the water overflows to the coast.

In the latter case, the toughness of the sensor in resisting the onslaught of the overflowing ocean waves depends on how the designs are made, ranging from a prototype protective box that must be waterproof and a prototype buffer pole strong against large wave shocks. However, in this research we need to add more variables that can be used to conduct research or research on tsunami, not only the receding water and vibration due to earthquake based on sea that is detected by the sensor.

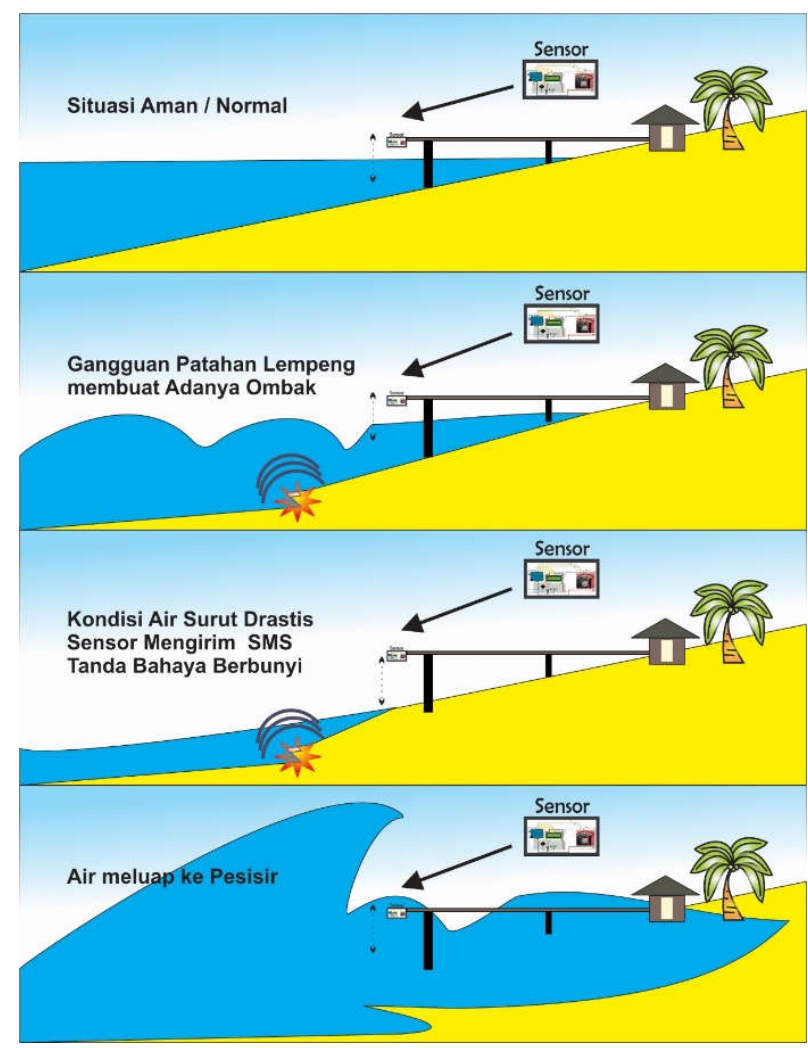

Fig 7. Prototype Process Works and Tsunami condition

\section{CONCLUSION}

This prototype successfully tested and run well, the next step is to put the prototype on the beach with sea water level and sensor $<=319 \mathrm{~cm}$. because beyond that range or larger, the sensor can not read the object that is sea water. So it is necessary to have specific data about sea water conditions and the resulting vibration.

From the prototype made it is expected to reduce the death of coastal populations due to a sudden tsunami and no sign of any, so that with this prototype can provide information as soon as possible using prototype made based on early indications of tsunami disaster.

\section{REFERENCES}

[1] Bahga, Arshdeep; Madisetti, Vijay; Internet Of Things A hands on Approach, Universities Press, India. 2015.

[2] Oppenheim Alan V, Willsky Alan S, Sinyal dan Sistem Jilid 1 Edisi ke 2, Penerbit Erlangga, Jakarta, 1997.

[3] Purdum, Jack; " Beginning C for Arduino, Learn C Programming for the Arduino", Second Edition, Technology in Action Press, 2015.

[4] Boloor Jagadish Adith, “ Design and build fantastic projects and devices using the Arduino platform ", Packt Publishing Ltd. India, 2015.

[5] Adith Jagdish Boloor, Samarth Shah, Utsav Shah, Marco Schwartz; "Arduino: Building LED and Espionage Projects "; Packt Publishing Ltd, India, 2016.

[6] Samarth Shah, Utsav Shah; "Arduino BLINK Blueprints"; Packt Publishing Ltd, 2016.

[7] Marco Schwartz, Oliver Manickum; “ Programming Arduino with LabVIEW"; Packt Publishing Ltd, India, 2015 